\title{
CORRESPONDENCE.
}

\section{THE ASSIGNATION OF AN ALIMENTARY LIFERENT.}

\section{To the Editor of the Transactions of the Faculty of Actuaries.}

SIR,-In connection with applications for loans, the question occasionally arises whether an Assignation of an alimentary liferent (in so far as in excess of a sufficient alimentary provision) would be effectual, and the following case is of interest as illustrating some of the objections to relying on such a security.

The Court of Session (First Division, 12th June 1908, Cuthbert v. Cuthbert's Trustees) was asked to decide (1) whether a liferenter, entitled to half the income of an estate for his lifecent alimentary use allenarly and free from his debts and deeds and the diligence of his creditors, had power to grant a valid and effectual assignation to $£ 2100$ per annum of that income, and if not (2) whether he could grant a valid and effectual assignation to his liferent provision in so far as in excess of a sufficient alimentary income, and if so (3) whether in the circumstances $£ 1000$ per annum was a sufficient alimentary provision.

It was pointed out that it cannot be foretold with certainty what the future income of a fund will be, nor can it be known whether a sum sufficient for the aliment of a person in one year will remain sufficient for his aliment in all time. A Court thus appears to be precluded from expressing an opinion to the effect either that an assignation of any specified sum will leave a sufficient alimentary provision or that any specified portion of the income will be sufficient for aliment in the future. Moreover, while the principle has been recognised that such portion of an alimentary income as is in excess of the amount required for an alimentary provision may, year by year, be made available for the creditors of a liferenter, it cannot be known what claims by creditors will emerge in the future, and a decision of the validity of the assignation would not be res judicata between the assignees and the alimentary creditors whose claims might emerge from year to year.

On these grounds the case was dismissed as incompetent.

The case is reported in The Scottish Law Reporter of 15th July, and my information is taken from that report.

$$
\text { I am, etc., }
$$

JOHN EDGAR.

26 GEORAE STREET,

FindBuraH, 10th November 1908. 